Article

\title{
Epilepsy in Tubulinopathy: Personal Series and Literature Review
}

\author{
Romina Romaniello ${ }^{1}$, Claudio Zucca ${ }^{2}$, Filippo Arrigoni ${ }^{3}$, Paolo Bonanni ${ }^{4}$, Elena Panzeri ${ }^{5}$, \\ Maria T. Bassi ${ }^{5}$ and Renato Borgatti ${ }^{1, *}$ D \\ 1 Neuropsychiatry and Neurorehabilitation Unit, Scientific Institute, IRCCS Eugenio Medea, Bosisio Parini, \\ 23842 Lecco, Italy \\ 2 Clinical Neurophysiology Unit, Scientific Institute, IRCCS Eugenio Medea, Bosisio Parini, 23842 Lecco, Italy \\ 3 Neuroimaging Lab, Scientific Institute, IRCCS Eugenio Medea, Bosisio Parini, 23842 Lecco, Italy \\ 4 Epilepsy and Clinical Neurophysiology Unit, Scientific Institute, IRCCS Eugenio Medea, Conegliano, \\ 31015 Treviso, Italy \\ 5 Laboratory of Molecular Biology, Scientific Institute, IRCCS Eugenio Medea, Bosisio Parini, 23842 Lecco, Italy \\ * Correspondence: renato.borgatti@bp.lnf.it; Tel.: +39-031-877-111
}

Received: 4 June 2019; Accepted: 28 June 2019; Published: 2 July 2019

\begin{abstract}
Mutations in tubulin genes are responsible for a large spectrum of brain malformations secondary to abnormal neuronal migration, organization, differentiation and axon guidance and maintenance. Motor impairment, intellectual disability and epilepsy are the main clinical symptoms. In the present study 15 patients from a personal cohort and 75 from 21 published studies carrying mutations in TUBA1A, TUBB2B and TUBB3 tubulin genes were evaluated with the aim to define a clinical and electrophysiological associated pattern. Epilepsy shows a wide range of severity without a specific pattern. Mutations in TUBA1A (60\%) and TUBB2B (74\%) and TUBB3 (25\%) genes are associated with epilepsy. The accurate analysis of the Electroencephalogram (EEG) pattern in wakefulness and sleep in our series allows us to detect significant abnormalities of the background activity in $100 \%$ of patients. The involvement of white matter and of the inter-hemispheric connection structures typically observed in tubulinopathies is evidenced by the high percentage of asynchronisms in the organization of sleep activity recorded. In addition to asymmetries of the background activity, excess of slowing, low amplitude and Magnetic Resonance (MR) imaging confirm the presence of extensive brain malformations involving subcortical and midline structures. In conclusion, epilepsy in tubulinopathies when present has a favorable evolution over time suggesting a not particularly aggressive therapeutic approach.
\end{abstract}

Keywords: tubulin genes; epilepsy; malformations cortical development; EEG; TUBA1A; TUBB2B; TUBB3

\section{Introduction}

In the last two decades, more evidence has been provided about the role of genes in determining epilepsy [1-5]. Among these genes, some play a role in neuronal membrane electrical stabilization [1], while others are involved in or regulate neuronal proliferation, migration and postmigrational cortical organization during fetal brain development. Mutations in this last group of genes lead to major structural cortical abnormalities (malformations of cortical development, MCDs) which are associated with specific neuroradiological patterns [2,3]. In the last years, the improvement and availability of new molecular genetics and neuroradiology techniques allowed a great increase of studies on the genes involved in the processes of cerebral cortical development, and more than 100 genes have been reported to date [2,4-7]. A key role in determining MCDs is played by microtubules (MTs), proteins that provide structures and forces needed by neurons to migrate and to develop 
axonal and dendritic processes [8]. Tubulins represent the major constituents of microtubules; they are dimeric proteins consisting of two closely $\alpha$ and $\beta$ related subunits [9] encoded by tubulin genes (i.e., TUBA1A, TUBB2B, TUBB3, TUBB4A, TUBB2A, TUBB, TUB8A). Tubulin proteins play a key role in several cellular processes crucial for a proper cortical development during neuronal proliferation, migration, differentiation, cortical laminar organization and axonal guidance of the radial glia (axon outgrowth and maintenance) $[10,11]$ Mutations in the $\alpha$ - and $\beta$-tubulin genes, related to the functional area of the protein involved, lead to a complex and wide spectrum of cerebral malformations defined "Tubulinopathies" [12-14]. Typically, affected patients show complex malformations of cortical development (e.g., polymicrogyria, lissencephaly, pachygyria, subcortical band heterotopia, schizencephaly etc.), basal ganglia dysmorphisms (frequently characterized by an agenesis or thinning of the anterior limb of internal capsule - ALIC) and commissural anomalies (different combinations of anterior commissure and corpus callosum agenesis or dysmorphisms) [15-39]. The abnormalities of the posterior fossa have been systematically described only in the last years. The most frequent findings are cortical cerebellar dysplasia, brainstem asymmetries and brainstem clefts [40-42].

The present study describes in detail the tubulin genes family and its role in brain development and in epileptogenic mechanisms. EEG and clinical data of six epileptic patients from a cohort of 15 patients carrying mutations in TUBA1A, TUBB2B and TUBB3 tubulin genes are analyzed as well as a literature review on the role of these genes and epilepsy is reported with the aim to define a specific associated epileptic pattern.

\section{Material and Methods}

Fifteen patients (seven males, age range 4-56 years) carrying mutations in TUBA1A, TUBB2B and TUBB3 genes were enrolled in the study from a personal cohort of patients. Blood samples were obtained from the patients and available parents and genomic DNA was extracted using conventional strategies. All patients were screened using a targeted next generation sequencing approach with a gene panel including 149 genes known to be involved in MCD and Corpus Callosum Agenesis (CCA) (the gene list is reported in Supplementary file). To exclude variants or mutations in epilepsy genes, all patients were also screened by using a NGS gene panel including 170 genes known to be mutated in epileptic encephalopathies and other genetic forms of epilepsy (the gene list is reported in Supplementary file). The targeted regions were designed to include coding exons with intronic $50 \mathrm{bp}$ flanking sites and $3^{\prime}$ and $5^{\prime}$ untranslated regions (UTRs) by using the SureDesign system (Agilent Technologies, Santa Clara, CA, USA). The sequencing libraries were prepared from genomic DNA by using a Sure Select enrichment system (Agilent Technologies). Targeted libraries were run on MiSeq/NextSeq platform according to the manufacturer's instructions (Illumina, San Diego, CA, USA). ANNOVAR was used for annotation against the RefSeq database and the Single Nucleotide Polymorphism databases. The filtering strategy we applied led us to select only variants located in the coding regions including the splice site (synonymous variants were excluded), variants that exhibited a minor allele frequency of less than $1 \%$ or were not present in variant databases including those of the 1000 Genomes Project, the Exome Aggregation Consortium (ExAC) and the NHLBI exome sequencing project ESP6500. On average, $98.66 \%$ and $99.3 \%$ of bases were covered by at least 10 and 20 sequence reads, respectively. Sanger Sequencing was used to confirm all the identified variants. For each patient, the identified mutation was tested in both parents when available to assess whether it occurred de novo or was inherited from one of the parents. Mutations nomenclature is based on RefSeq NM_006009.3 (TUBA1A), NM_178012.4 (TUBB2B) and NM_6086.2 (TUBB3) considering the A of the ATG as nucleotide 1 and follows the guidelines of the Human Genome Variation Society.

Novel variants were tested against different databases: 1000 genomes, Exome Variant Sever, dbSNP, HGMD (Human Gene Mutation Database) and ExAC (Exome Aggregation Consortium) databases. To confirm the pathogenicity of the mutations, we used web-based prediction programs: MutPred (http://mutpred.mutdb.org), PolyPhen-2 (http//genetics.bwh.harvard.edu/pph2), PROVEAN 
(http://provean.jcvi.org/), Mutation taster (http://mutationtaster.org) and SIFT (http://sift.jcvi.org/www/ SIFT_seq_submit2.html).

All patients had a brain MRI scan performed either on a $1.5 \mathrm{~T}$ or $3 \mathrm{~T}$ MR scanner for clinical indication using the local departmental protocol. For each patient, MRI included a three-dimensional (3D) T1-weighted sequence and two-dimensional (2D)-Turbo Spin Echo T2-weighted sequences on at least two orthogonal planes. All the exams were reviewed by an experienced neuroradiologist who classified the neuroimaging finding of each patient.

Clinical data on epilepsy symptomatology and electrophysiological records of all patients were collected in detail. Particularly were identified and classified: age of seizure onset, type of seizure, epileptic syndrome and the response to anti-epileptic treatment. All the EEG recordings of the patients included in the study were reviewed and classified, according to the characteristics of background activity during wakefulness and during sleep and the presence and the characteristics of slow and epileptiform abnormalities.

A MEDLINE search on PubMed and OMIM Programs using [Tubulin gene mutations in human brain] and [epilepsy] as inclusion criteria yielded 21 studies published between from 2007 January to March 2019.

The Ethics Committee of the E. Medea Scientific Institute approved the study. A written informed consent was obtained from all participating families.

\section{Results}

Clinical and EEG data: six out of 15 patients presented epileptic seizures (40\%) (three with TUBA1A gene mutation and three with TUBB2B gene mutation; none TUBB3 carrying gene mutation showed epilepsy). In the affected patients, epilepsy started as epileptic encephalopathy (more often a West syndrome). Subsequently the syndrome evolved towards a focal epilepsy that in the vast majority of cases is well controlled by drug therapy. The most used drug was Sodium Valproate (see Table 1). A close correlation between the presence of MCDs and epilepsy can be observed. All the epileptics subjects but one $(5 / 6 ; 83 \%)$ showed MCD at brain MRI, while in 5/9 $(55.5 \%)$ non-epileptics patients an MCD was absent.

EEG data were collected in 12 out of 15 patients, and 45 polygraphic recordings of EEG have been analyzed; in 10 patients, several recordings during sleep were also available. Background activity, slow and epileptiform abnormalities collected both during wake and sleep EEG recordings are shown in Table 1 . The background activity is significantly abnormal in $100 \%$ of patients. Slow and epileptiform recorded anomalies are strictly correlated with the localization of the cortical malformations revealed by MRI (see Figure 1). A high percentage of asynchronisms in the organization of sleep activity was detected. Non-epileptic myoclonus over the surface EMG districts (usually deltoid muscle of both sides) was documented. In one case, paroxysmal EEG abnormalities are evoked by intermittent light stimulation. 
Table 1. Electrophysiological findings of our series.

\begin{tabular}{|c|c|c|c|c|c|c|c|c|c|c|c|}
\hline & $\begin{array}{l}\text { Gender, } \\
\text { Age }\end{array}$ & $\begin{array}{l}\text { Epileptic } \\
\text { Syndrome }\end{array}$ & $\begin{array}{l}\text { Seizure } \\
\text { Type }\end{array}$ & $\begin{array}{l}\text { Age at } \\
\text { Onset }\end{array}$ & Awake EEG BA & Awake EEG EA & Sleep EEG BA & $\begin{array}{l}\text { Sleep EEG } \\
\text { EA }\end{array}$ & $\begin{array}{l}\text { Response } \\
\text { to AEDs }\end{array}$ & MCDs on MRI & Genetic Findings \\
\hline \multicolumn{12}{|c|}{ EPILEPTIC PATIENTS } \\
\hline \multicolumn{12}{|c|}{ TUBA1A } \\
\hline P45617 & $\begin{array}{c}\mathrm{F}, \\
13 \mathrm{yrs} 3 \\
\text { mo }\end{array}$ & $\begin{array}{c}\text { Focal } \\
\text { symptomatic } \\
\text { epilepsy }\end{array}$ & $\begin{array}{l}\text { Spasms, } \\
\text { FS }\end{array}$ & $\begin{array}{l}18 \mathrm{mo} \\
3 \mathrm{yrs}\end{array}$ & $\begin{array}{l}\text { Irregular Low } \\
\text { voltage }\end{array}$ & 0 & $\begin{array}{c}\text { Irregular } \\
\text { BFA } \\
\text { Asynchronous }\end{array}$ & $\begin{array}{l}\text { SA EA } \\
\text { Right TO }\end{array}$ & $\begin{array}{l}\text { Controlled } \\
\text { (ACTH; } \\
\text { VPA) }\end{array}$ & Perisylvian dysgyria & c. $466 C$ > G (p.R156G) \\
\hline P89815§ & $\begin{array}{c}\mathrm{F}, \\
3 \text { yrs } 3 \\
\text { mo }\end{array}$ & $\begin{array}{c}\text { Focal } \\
\text { symptomatic } \\
\text { epilepsy }\end{array}$ & FS & 21 days & $\begin{array}{l}\text { Irregular Asym } \\
\text { Slowing } \\
\text { BFA }\end{array}$ & $\begin{array}{l}\text { SA paroxysmal } \\
\text { Rght CO }\end{array}$ & $\begin{array}{l}\text { Irregular Asym } \\
\text { Asynchronous }\end{array}$ & $\begin{array}{l}\text { SA EA Right } \\
\text { CO Left CT } \\
\text { asynchronous }\end{array}$ & $\begin{array}{l}\text { Controlled } \\
\text { (LEV) }\end{array}$ & PMG-multi & c.4C > A (p.R2S) \\
\hline $17656 \S$ & $\begin{array}{c}\mathrm{M} \\
13 \mathrm{yrs} 4 \\
\text { mo }\end{array}$ & $\begin{array}{c}\text { Focal } \\
\text { symptomatic } \\
\text { epilepsy }\end{array}$ & $\begin{array}{l}\text { Myoclonic, } \\
\text { focal SE, } \\
\text { SF }\end{array}$ & $3 \mathrm{mo}$ & $\begin{array}{l}\text { Irregular } \\
\text { Slowing }\end{array}$ & 0 & $\begin{array}{l}\text { Irregular } \\
\text { Asym }\end{array}$ & $\begin{array}{c}\text { SA } \\
\text { paroxysmal } \\
\text {-EA Left C } \\
\text { PO }\end{array}$ & $\begin{array}{l}\text { Controlled } \\
\text { (VPA, ETS) }\end{array}$ & No MCD & c.1169G > A (p.R390H) \\
\hline \multicolumn{12}{|c|}{ TUBB2B } \\
\hline P76712§ & $\begin{array}{c}\mathrm{M}, \\
10 \mathrm{yrs} 9 \\
\text { mo }\end{array}$ & $\begin{array}{c}\text { Focal } \\
\text { symptomatic } \\
\text { epilepsy }\end{array}$ & $\begin{array}{l}\text { Spasms, } \\
\text { FS }\end{array}$ & $18 \mathrm{mo}$ & $\begin{array}{c}\text { Irregular Asym } \\
\text { BFA }\end{array}$ & $\begin{array}{c}\text { SA } \\
\text { Left CT }\end{array}$ & $\begin{array}{l}\text { Irregular } \\
\text { Asym } \\
\text { BFA }\end{array}$ & $\begin{array}{l}\text { SA EA } \\
\text { Left CT and } \\
\text { diffuse }\end{array}$ & $\begin{array}{l}\text { Partially } \\
\text { controlled } \\
\text { (VPA) }\end{array}$ & $\begin{array}{l}\text { Generalized PMG + } \\
\text { SCH }\end{array}$ & c.1060T > C (p.C354R) de novo \\
\hline P38408§ & $\begin{array}{c}\text { F, } \\
16 \text { yrs } 8 \\
\text { mo }\end{array}$ & $\begin{array}{c}\text { Focal } \\
\text { symptomatic } \\
\text { epilepsy }\end{array}$ & $\begin{array}{l}\text { Spasm, } \\
\text { FS }\end{array}$ & $5 \mathrm{mo}$ & $\begin{array}{l}\text { Irregular Asym } \\
\text { Slowing } \\
\text { BFA }\end{array}$ & 0 & $\begin{array}{l}\text { Irregular } \\
\text { Asym } \\
\text { BFA } \\
\text { NEM }\end{array}$ & $\begin{array}{l}\text { SA EA } \\
\text { Right C }\end{array}$ & $\begin{array}{l}\text { Controlled } \\
\text { (VPA, LTG) }\end{array}$ & $\begin{array}{c}\text { Generalized PMG + } \\
\text { SCH }\end{array}$ & c.419G > C (p.G140A) de novo \\
\hline P78511 § & $\begin{array}{c}\mathrm{F} \\
39 \mathrm{yrs}\end{array}$ & $\begin{array}{c}\text { Focal } \\
\text { symptomatic } \\
\text { epilepsy }\end{array}$ & $\begin{array}{l}\text { Spasms, } \\
\text { FS }\end{array}$ & $7 \mathrm{mo}$ & $\begin{array}{c}\text { Irregular } \\
\text { Slow voltage } \\
\text { BFA }\end{array}$ & $\begin{array}{l}\text { SA paroxysmal } \\
\text { bilateral } \\
\text { diffuse } \\
\text { positive ILS }\end{array}$ & NA & NA & $\begin{array}{c}\text { Controlled } \\
\text { (ACTH, PB, } \\
\text { CBZ) }\end{array}$ & $\begin{array}{c}\text { Symp_Gyr, periv } \\
\text { heterotopia, } \\
\text { subcortical linear } \\
\text { heterotopia, small } \\
\text { temporal lobes }\end{array}$ & $\begin{array}{l}\text { c.1080_1084delCCTGAinsACATCTTC } \\
\text { [p.L361_K362delinsHLQ) de novo }\end{array}$ \\
\hline
\end{tabular}


Table 1. Cont

\begin{tabular}{|c|c|c|c|c|c|c|c|c|c|c|c|}
\hline & $\begin{array}{l}\text { Gender, } \\
\text { Age }\end{array}$ & $\begin{array}{l}\text { Epileptic } \\
\text { Syndrome }\end{array}$ & $\begin{array}{l}\text { Seizure } \\
\text { Type }\end{array}$ & $\begin{array}{c}\text { Age at } \\
\text { Onset }\end{array}$ & Awake EEG BA & Awake EEG EA & Sleep EEG BA & $\begin{array}{c}\text { Sleep EEG } \\
\text { EA }\end{array}$ & $\begin{array}{c}\text { Response } \\
\text { to AEDs }\end{array}$ & MCDs on MRI & Genetic Findings \\
\hline \multicolumn{12}{|c|}{ NON EPILEPTIC PATIENTS } \\
\hline \multicolumn{12}{|c|}{ TUBA1A } \\
\hline P78411 $§$ & $\begin{array}{c}\mathrm{M} \\
7 \mathrm{yrs} 6 \\
\mathrm{mo}\end{array}$ & no & no & I & $\begin{array}{l}\text { Irregular Asym } \\
\text { Slowing } \\
\text { BFA }\end{array}$ & no & $\begin{array}{c}\text { Irregular } \\
\text { Asym } \\
\text { BFA } \\
\text { Asynchronous }\end{array}$ & \begin{tabular}{l}
\multicolumn{1}{c}{ SA C } \\
bilateral Left \\
predominance
\end{tabular} & I & No MCD & c.175G > A (p.G59S) de novo \\
\hline $\begin{array}{c}\mathrm{P} 113708 \S \\
\mathrm{I}-3\end{array}$ & $\begin{array}{c}\mathrm{M} \\
56 \mathrm{yrs} 4 \\
\text { mo }\end{array}$ & no & no & l & NA & & NA & NA & l & Perisylvian-PMG & c.161G > A (p.S54N) \\
\hline $\begin{array}{c}\text { P113708 § } \\
\text { II-1 }\end{array}$ & $\begin{array}{c}\mathrm{F}, \\
25 \mathrm{yrs} 4 \\
\text { mo }\end{array}$ & no & no & l & $\begin{array}{l}\text { Irregular } \\
\text { Slowing } \\
\text { Low voltage }\end{array}$ & 0 & NA & NA & I & Perisylvian-PMG & c. $161 \mathrm{G}>\mathrm{A}(\mathrm{p} . \mathrm{S} 54 \mathrm{~N})$ \\
\hline $\begin{array}{c}\mathrm{P} 113708 \S \\
\mathrm{II}-2\end{array}$ & $\begin{array}{c}\mathrm{F}, \\
25 \mathrm{yrs} 4 \\
\text { mo }\end{array}$ & no & no & l & $\begin{array}{c}\text { Irregular } \\
\text { Slowing } \\
\text { Low voltage } \\
\text { BFA } \\
\end{array}$ & 0 & NA & NA & l & Perisylvian-PMG & c.161G > A (p.S54N) \\
\hline P76111§ & $\begin{array}{c}\text { F, } \\
12 \text { yrs } 3 \\
\text { mo }\end{array}$ & no & no & I & $\begin{array}{c}\text { Irregular Asym. } \\
\text { Slowing } \\
\text { BFA } \\
\text { Low voltage }\end{array}$ & 0 & $\begin{array}{l}\text { Irregular Asym } \\
\text { Asynchronous }\end{array}$ & $\begin{array}{l}\text { SA bilateral } \\
\text { diffuse }\end{array}$ & l & No MCD & c.1160C > T (p.A387V) de novo \\
\hline \multicolumn{12}{|c|}{ TUBB3 } \\
\hline P17816 § & $\begin{array}{c}\mathrm{F}, \\
4 \mathrm{yrs}\end{array}$ & no & no & 1 & NO & NA & NA & NA & l & no $\mathrm{MCD}$ & c.1228G > A (p.E410K) de novo \\
\hline $105814^{\S}$ & $\begin{array}{c}\mathrm{M} \\
4 \mathrm{yrs} 9 \\
\mathrm{mo}\end{array}$ & no & no & l & $\begin{array}{l}\text { Irregular } \\
\text { Slowing }\end{array}$ & 0 & $\begin{array}{c}\text { Irregular } \\
\text { Asym } \\
\text { Asynchronous }\end{array}$ & $\begin{array}{l}\text { SA Right PO } \\
\text { and diffuse }\end{array}$ & I & no MCD & c.862G > A (p.E288K) de novo \\
\hline P120818 & $\begin{array}{c}\mathrm{M}, \\
34 \mathrm{yrs}\end{array}$ & no & no & l & NA & NA & NA & NA & l & No MCD & c.689C > T (p.S230L) \\
\hline P109418 & $\begin{array}{c}\mathrm{M}, \\
12 \mathrm{yrs}\end{array}$ & no & no & l & $\begin{array}{l}\text { Irregular } \\
\text { Slowing }\end{array}$ & $\begin{array}{c}\text { SA } \\
\text { PO bilateral }\end{array}$ & $\begin{array}{c}\text { Irregular } \\
\text { Asynchronous }\end{array}$ & $\begin{array}{c}\text { SA } \\
\text { paroxysmal } \\
\text { PO bilateral }\end{array}$ & l & Perisylvian PMG & c.728C > T (p.P243L) \\
\hline
\end{tabular}

AEDs: Antiepileptic drugs; Asym: asymmetric; BA: Background activity; BFA: burst of fast activity; C: central; cn: cranic nerve; EA: Epileptiform Abnormalities; F: female; FS: focal seizures; ISL: intermittent light stimulation; L: Left; LTG: Lamotrigine; M: male; MCDs: malformations of cortical development; mo: months; NA: not available; NEM: not-epileptic myoclonus; no: not observed; O: occipital; P: parietal; PMG: Polymicrogyria; PMG-multi: multifocal Polymicrogyria; R: right; S: Sleep; SCH: Schizencephaly; Symp_Gyr: simplified gyral

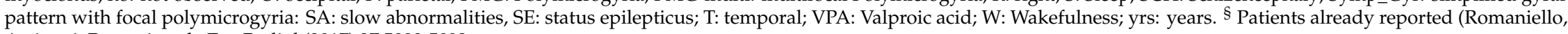
Arrigoni, Panzeri et al., Eur Radiol (2017) 27:5080-5092. 


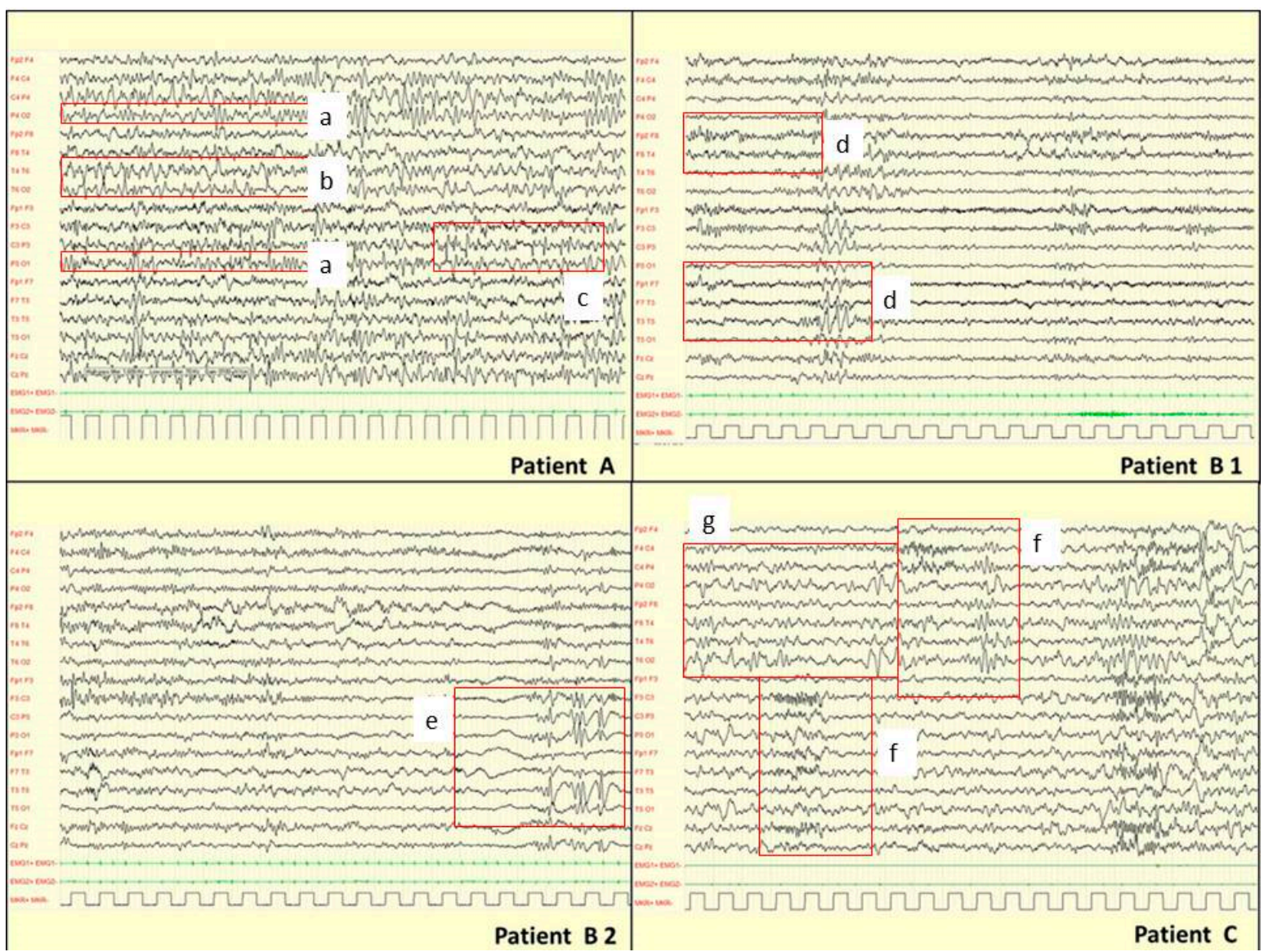

Figure 1. EEG findings in TUBA1A, TUBB2 and TUBB3 genes mutations. Patient A [P89815] (33 months) has a mutation in TUBA1A gene and at MRI multifocal PMG. During drowsiness: asymmetric background activity (square: a). Paroxysmal slow abnormalities over right posterior regions (square: b). Asynchronous epileptiform abnormalities over left central areas (square: c). Patient B [P76712] (8 years) has a mutation in TUBB2B gene. B1 EEG during wakefulness: asymmetry of the background activity and paroxysmal slow abnormalities over left centro-temporal areas (square: d). B2 EEG during drowsiness: epileptiform abnormalities over left centro-temporal areas (square e). Patient's MRI showed a schizencephaly in left centro-temporal areas consistent to EEG abnormalities. Patient C [P105814] (15 months) has a mutation in TUBB3 gene. EEG during 2-3 non-REM sleep: asymmetric and asynchronous background activity (square f). Diphasic slow abnormalities over right parietal and occipital areas (square g). In this patient, no epileptiform abnormalities were recorded according with the absence of MCDs on MRI.

Genetic data: 13 variants were identified in TUBA1A (8), TUBB2B (3), TUBB3 (4) genes in the 15 patients. Ten variants had been previously reported [41], while three variants are novel (one in TUBA1A and two in TUBB3 genes). In nine families, segregation has been tested: all variants resulted to be de novo apart from TUBA1A p.(S54N), which was inherited by the two twin sisters from their affected father (family P113708) [41]. The genetic screening performed for all patients with both the targeted gene panel for MCD genes and a targeted panel for epilepsy genes (see Supplementary file) did not detect any additional mutations.

Neuroradiological data: mutated patients with epilepsy showed multifocal polymicrogyria (1), generalized polymicrogyria and schizencephaly (2), simplified gyral pattern and linear subcortical heterotopia (1), dysgiria (1) and no MCD in one case. Mutated patients with no epilepsy showed perisylvian polymicrogyria in four cases and normal cortex in five cases. The imaging findings of two patients are reported as example of MCDs and other brain malformations affecting patients with mutations in tubulin genes (see Figure 2). 

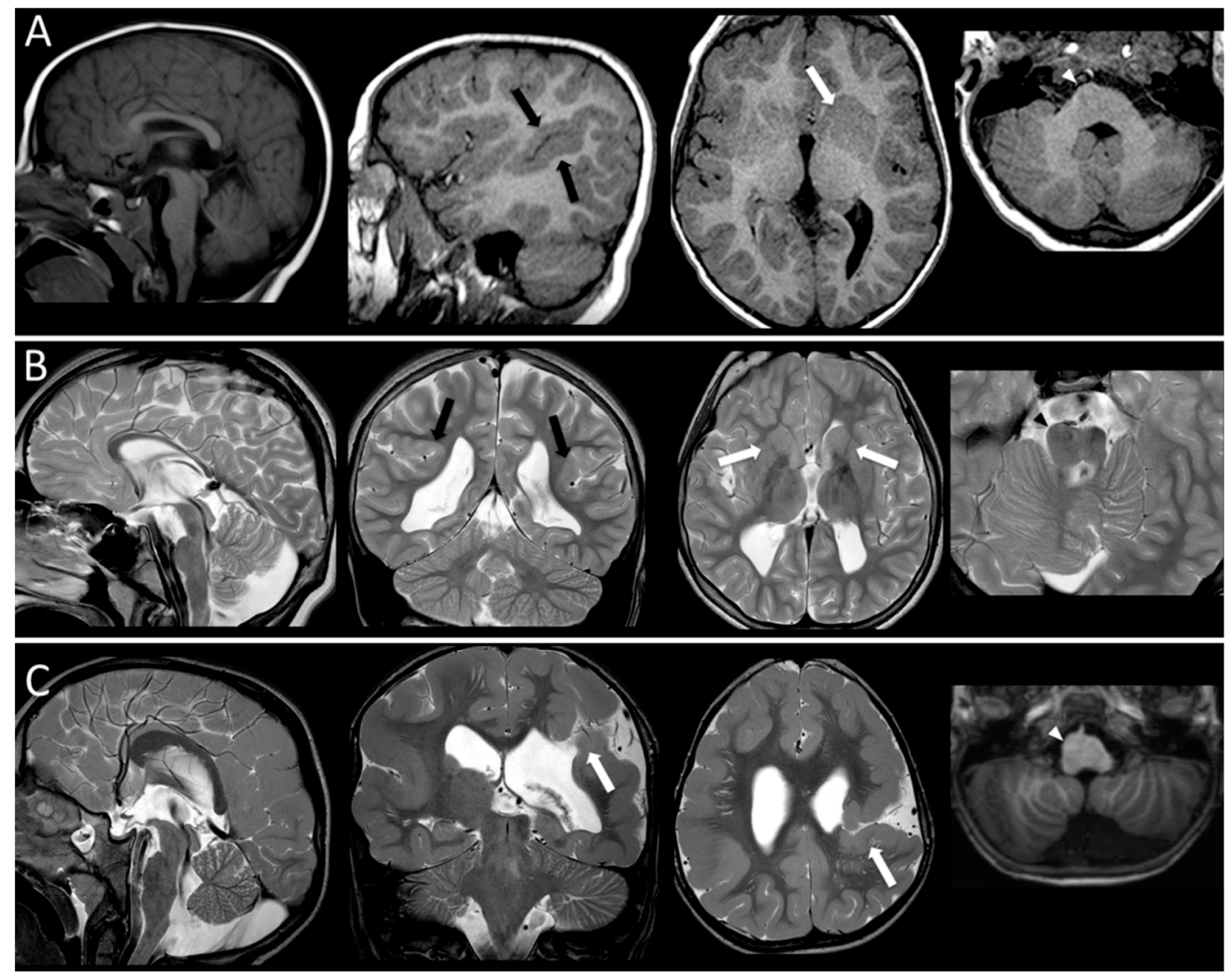

Figure 2. MR imaging findings in three patients. Patient A [P109418] has a mutation in TUBB3 gene. T1-weighted images show a thin and short corpus callosum, perisylvian polymicrogyria (black arrow), a severe thinning/agenesis of the ALIC (white arrow) and brainstem asymmetry (arrowhead pointing at enlarged pons). Patient B [P45617] carries a mutation in TUBA1A gene. Thin corpus callosum, dysgyric cortex in perisylvian areas (black arrows), bilaterally thinned ALIC (white arrows) and pons asymmetry (arrowhead pointing at enlarged pons) are shown on T2-weighted images Patient C [P76712] carries a mutation in TUBB2B gene. He has a malformed corpus callosum and brainstem, with a thickened ponto-medullary junction and brainstem asymmetry (arrowhead pointing at enlarged medulla). He has also a complex cortical malformation with diffuse bilateral polymicrogyria and schizencephaly in the left hemisphere (arrows).

Literature data: Figure 3 summarizes results derived from literature review. The number of mutations for each gene and domain and the frequency and characteristics of epileptic features associated are reported. Among patients described in literature carrying mutations in TUBA1A gene, epilepsy was reported in $28 \%$ (44/155), while it was described in $49 \%(19 / 39)$ of TUBB2B and in $5 \%$ (3/62) of TUBB3 mutated patients. Incidence of mutations associated with epilepsy is not significantly different among the tubulin domains for TUBA1A and TUBB2B genes, while in the TUBB3 gene, the $C$-domain does not show mutations related to epileptic features. It is to be noted that the mutations described in this domain do not correlate with MCD phenotype, but with CFEOM (Congenital Fibrosis of the Extraocular Muscles). The seizure onset had a range between birth to 3 years of age. The most frequent seizures types were focal (39\% TUBA1A; $47 \%$ TUBB2B) and spasms $(26 \%$ TUBA1A; $33 \%$ TUBB2B). Absence and myoclonic seizures were reported in $6 \%$ (TUBA1A) and 7\% (TUBB2B), respectively. Tonic-clonic seizures were described in $18 \%$ (TUBA1A) and $13 \%$ (TUBB2B), while tonic seizures in $8 \%$ (TUBA1A) and 13\% (TUBB2B). Only in patients carrying TUBA1A gene mutations, focal status epilepticus was observed. Regarding TUBB3 gene mutations, only febrile seizures were described. Seizure control was achieved in $33 \%$ of cases carrying TUBA1A gene mutations and in $72 \%$ of TUBB2B mutated patients. The most used drugs were: Sodium Valproate, Phenobarbital, 
Carbamazepine, Levetiracetam, Lamotrigine. Refractory seizures were reported only in TUBA1A gene mutations (56\%) (data summarized in supplementary material Tables S1 and S2).

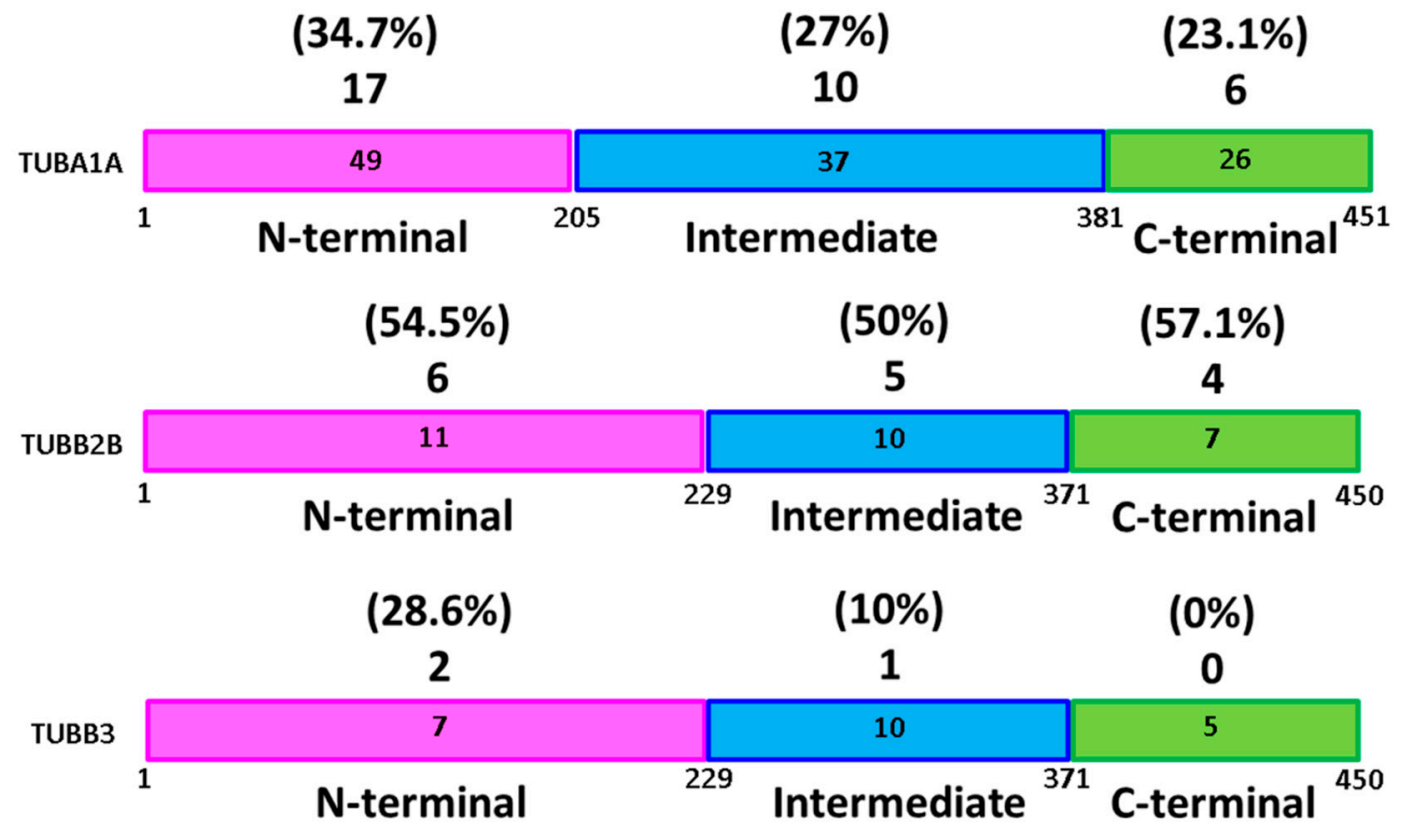

\begin{tabular}{|c|c|c|c|c|c|c|c|c|c|c|c|c|}
\hline & \multicolumn{4}{|c|}{ TUBA1A } & \multicolumn{4}{|c|}{ TUBB2B } & \multicolumn{4}{|c|}{ TUBB3 } \\
\hline & \begin{tabular}{|l|} 
Mutations \\
\end{tabular} & Patients & $\begin{array}{l}\text { Mutations } \\
\text { associated } \\
\text { with } \\
\text { epilepsy }\end{array}$ & $\begin{array}{l}\text { Epileptic } \\
\text { Patients }\end{array}$ & Mutations & Patients & $\begin{array}{l}\text { Mutations } \\
\text { associated } \\
\text { with epilepsy }\end{array}$ & $\begin{array}{l}\text { Epileptic } \\
\text { Patients }\end{array}$ & \begin{tabular}{|l|} 
Mutations \\
\end{tabular} & Patients & $\begin{array}{l}\text { Mutations } \\
\text { associated } \\
\text { withepilepsy }\end{array}$ & $\begin{array}{l}\text { Epileptic } \\
\text { Patients }\end{array}$ \\
\hline $\begin{array}{l}\mathrm{N} \text {-TERM } \\
\text { Our series }\end{array}$ & $\begin{array}{c}49 \\
4\end{array}$ & $\begin{array}{l}57 \\
6\end{array}$ & $\begin{array}{c}17 \\
2\end{array}$ & $\begin{array}{c}18 \\
2\end{array}$ & $\begin{array}{c}11 \\
1\end{array}$ & $\begin{array}{c}15 \\
1\end{array}$ & $\begin{array}{l}6 \\
1\end{array}$ & $\begin{array}{l}8 \\
1\end{array}$ & $\begin{array}{l}7 \\
0\end{array}$ & $\begin{array}{c}11 \\
0\end{array}$ & $\begin{array}{l}2 \\
0\end{array}$ & $\begin{array}{l}2 \\
0\end{array}$ \\
\hline $\begin{array}{l}\text { INTERMEDIATE } \\
\text { Our series }\end{array}$ & $\begin{array}{c}37 \\
0\end{array}$ & $\begin{array}{c}50 \\
0\end{array}$ & $\begin{array}{c}10 \\
0\end{array}$ & $\begin{array}{c}13 \\
0\end{array}$ & $\begin{array}{c}10 \\
2\end{array}$ & $\begin{array}{c}13 \\
2\end{array}$ & $\begin{array}{l}5 \\
2\end{array}$ & $\begin{array}{l}6 \\
2\end{array}$ & $\begin{array}{c}10 \\
3\end{array}$ & $\begin{array}{c}30 \\
3\end{array}$ & $\begin{array}{l}1 \\
0\end{array}$ & $\begin{array}{l}1 \\
0\end{array}$ \\
\hline $\begin{array}{l}\text { C-TERM } \\
\text { Our series }\end{array}$ & $\begin{array}{c}26 \\
2\end{array}$ & $\begin{array}{c}48 \\
2\end{array}$ & $\begin{array}{l}6 \\
1\end{array}$ & $\begin{array}{c}13 \\
1\end{array}$ & $\begin{array}{l}7 \\
0\end{array}$ & $\begin{array}{c}11 \\
0\end{array}$ & $\begin{array}{l}4 \\
0\end{array}$ & $\begin{array}{l}5 \\
0\end{array}$ & $\begin{array}{l}5 \\
1\end{array}$ & $\begin{array}{c}21 \\
1\end{array}$ & $\begin{array}{l}0 \\
0\end{array}$ & $\begin{array}{l}0 \\
0\end{array}$ \\
\hline TOTAL & 112 & 155 & 33 & 44 & 28 & 39 & 15 & 19 & 22 & 62 & 3 & 3 \\
\hline
\end{tabular}

Figure 3. Schematic representations of the functional domains of TUBA1A, TUBB2B and TUBB3. The numbers in the boxes show how many mutations are described for each tubulin domain by distinguishing literature and our series, while above the protein schemes are reported the number of mutations associated with epilepsy and the corresponding percentage.

\section{Discussion}

The role of $\alpha$ - and $\beta$-tubulin genes mutations in determining epilepsy is complex, depending on the way they alter the dynamic properties and functions of microtubules. The main role in causing epilepsy is played by mutations that disrupt stability of MTs, which are primarily involved in neuronal migration and organization, while perturbations of the microtubule dynamic, which have a crucial function in the axonal growth and guidance, are less frequently associated with epileptic phenotypes [43-45].

Tubulin genes play a key role in several pathways of cortical development such as other genes encoding microtubule-related proteins (i.e., Lissencephaly 1, Doublecortin, Filamin A or Reelin genes) and when mutated, may cause specific brain malformations strictly associated with epilepsy. Nevertheless, while each of these last genes is correlated with a typical epileptic phenotype (concerning onset, frequency and type of seizures and response to therapy), no specific epileptic pattern was found in tubulinopathies. Despite the complexity of the cerebral malformations and the severity of intellectual disabilities described, epilepsy does not seem to be one of the most serious features of the tubulin related clinical picture. When present, it is described with a wide range of severity (from a mild clinical presentation and spontaneous regression in most of patients, to intractable seizures in 
rare cases), without a specific clinical pattern [46-48]. An explanation for the scanty epileptogenicity of MCDs in tubulinopathies compared to MCDs due to other genes mutations may be the coexisting involvement of basal ganglia and cerebellum [23,28]. In fact literature data [49] support the presence of a "filtering effect" of the basal ganglia which contrasts the spread of ictal epileptiform activity. Other evidences suggest that the cerebellum exerts an inhibitory effect over epileptiform discharges; animal and human studies demonstrated that cerebellar stimulation reduces intensity or shortens seizure [50].

Among the $\alpha$ - and $\beta$-tubulin genes, TUBA1A (28\% of the cases) and TUBB2B gene $(49 \%)$ are those more frequently associated with epilepsy. On the contrary, mutations in the TUBB3 gene cause epilepsy only in $5 \%$ of cases. These findings are in line with our personal series, in which only TUBA1A and TUBB2B mutated patients showed epileptic seizures. Looking at the several genes mutations reported in literature (see Tables S1 and S2) it is evident that there are not significant recurring mutations in TUBA1A and in TUBB2B genes. On the contrary, in TUBB3 the mutation E410K is described in many families (13), but all are affected by an ocular motor disorder and no one is epileptic. Analyzing the distribution of mutations along different domains of each gene, none appears to be more frequently involved. Mutations associated with epileptic features are in TUBB2B gene equally distributed, while the N-terminal domain is more involved in TUBA1A and in TUBB3 genes. In this last gene, none of the five detected mutations (found in 21 patients) is associated with epilepsy. Intriguingly, in these patients MCDs are also absent. It is possible that this non-uniform distribution of mutations causing epilepsy among the three different genes domain can be attributed to their effect on tertiary structure and to the role played in the mechanisms underlying MCDs. Recently [51] a Tubg1 $1^{\mathrm{Y} 92 \mathrm{C} /+}$ mouse model was developed to investigate the consequence of some TUBG1 human mutation in MCDs. Cortical and hippocampal neuroanatomical anomalies were found associated with an increased epileptic cortical activities. Histological examinations in TUBA1A mutated brains revealed structural abnormalities of the cortex, a fractured pyramidal layer of the hippocampus, and defects attributed to impairment of neuronal migration mechanisms, similar to the mouse models of lissencephaly (LIS1, DCX, RELN) [51-54]. TUBB2B gene mutations influence the tubulin heterodimer folding and their incorporation into microtubules, thus leading to combinations of impairment in neuronal migration and radial glia dysfunction. Regarding the TUBB3 gene, this is involved primarily in axon guidance mechanisms scantly associated with MCDs and, consequently, with low levels of epileptogenicity. Nevertheless in a recent study, a role of TUBB3 in regulating epileptic seizures via GABA-A receptor-mediated synaptic transmission is shown, explaining the rare epileptic cases described TUBB3 mutated patients [55-60].

Concerning epileptic clinical manifestation, West syndrome is the most frequent clinical phenotype at onset in patients carrying TUBA1A and TUBB2B gene mutations. In spite of the severity of this epileptic syndrome (an early epileptic encephalopathy), the response to therapy and the clinical evolution, as described in literature and documented also in our series, are favorable in most cases. Usually, in 70-80\% of patients with brain malformations a severe symptomatic epilepsy syndrome is observed [61]. In at least $15 \%$ of the cases, these epileptic syndromes are characterized by a high frequency of seizures that are refractory to pharmacological treatment [62]. Despite the relatively small number of patients, it is noteworthy that, in our cohort epilepsy affected only six out 15 of cases, and seizures were refractory to treatment only in one patient. A complete clinical and EEG follow-up of our patients documented the evolution from an epileptic encephalopathy towards a focal epilepsy that, in the vast majority of cases, was well controlled by drug therapy. Five out six of the epileptic patients were seizure free at last control. This data is particularly relevant comparing to the extensions of the referred malformations and the consequent presence of severe neurological and neuropsychological impairments, that are typical risk factors linked to drug-resistant epilepsies. Detailed neurophysiological studies on brain electric activity in tubulinopathies are lacking, but the accurate analysis of the EEG pattern in wakefulness and sleep in our series allows us to detect significant abnormalities of the background activity in $100 \%$ of patients. The finding of abnormal bursts of fast activity can be expected in tubulinopathies in relation to the possibility of MCDs but 
frequently were also detected asymmetries of the activity, excess of slowing, low amplitude that are related to the presence of extensive brain malformations involving other structures beyond the cortex in particular subcortical and midline structures. Moreover, the involvement of white matter and of the inter-hemispheric connection structures is also evidenced by the high percentage of asynchronisms in the organization of sleep activity recorded by EEG in our series [63,64]. In addition, the polygraphic EEG recording allows to detect, in some cases, non-epileptic myoclonus that can be indicative of cerebellum cortical involvement as shown on MRI [41].

In conclusion, epilepsy in tubulinopathies when present has a less unfavorable trend compared with other forms of symptomatic epilepsies in childhood suggesting that, even in presence of a severe epileptic encephalopathy such as West syndrome at onset, no particularly aggressive therapeutic approach can be adopted. Thus, in these patients, early cognitive and behavioral rehabilitation interventions must be carried out in order to allow a better recovery and prognosis.

Supplementary Materials: The following are available online at http://www.mdpi.com/2073-4409/8/7/669/s1.

Author Contributions: R.R. performed acquisition of data and funding; drafted the manuscript. C.Z. performed the electrophysiological study and was involved in revising critically the manuscript. F.A. performed neuroradiological study and was involved in revising critically the manuscript. P.B. performed acquisition of data and the electrophysiological study. E.P. performed the molecular genetic studies. M.T.B. was involved in revising critically the manuscript and in acquisition of funding. R.B. conceived the study, participated in its design and drafted the manuscript.

Funding: This research was partially funded by Italian Ministry of Health., grant number RC 2018-2019 to R.R.; 5x1000 funds for biomedical research 2018 to R.R. and M.T.B.

Conflicts of Interest: The authors declare no conflict of interest.

\section{References}

1. Nabbout, R.; Scheffer, I.E. Genetics of idiopathic epilepsies. Handb. Clin. Neurol. 2013, 111, 567-578.

2. Barkovich, A.J.; Guerrini, R.; Kuzniecky, R.I.; Jackson, G.D.; Dobyns, W.B. A developmental and genetic classification for malformations of cortical development: Update. Brain 2012, 135, 1348-1369. [CrossRef]

3. Andrade, D.M. Genetic basis in epilepsies caused by malformations of cortical development and in those with structurally normal brain. Hum. Genet. 2009, 126, 1731-1793. [CrossRef]

4. Guerrini, R.; Dobyns, W.B. Malformations of cortical development: Clinical features and genetic causes. Lancet Neurol. 2014, 13, 710-726. [CrossRef]

5. Guerrini, R.; Barba, C. Malformations of cortical development and aberrant cortical networks: Epileptogenesis and functional organization. J. Clin. Neurophysiol. 2010, 27, 372-379. [CrossRef]

6. Kuzniecky, R. Epilepsy and malformations of cortical development: New developments. Curr. Opin. Neurol. 2015, 28, 151-157. [CrossRef]

7. Parrini, E.; Conti, V.; Dobyns, W.B.; Guerrini, R. Genetic basis of brain malformations. Mol. Syndr. 2016, 7, 220-233. [CrossRef]

8. Kato, M. Genotype-phenotype correlation in neuronal migration disorders and cortical dysplasias. Front Neurosci. 2015, 9, 181. [CrossRef]

9. Wu, Q.; Liu, J.; Fang, A.; Li, R.; Bai, Y.; Kriegstein, A.R.; Wang, X. The dynamics of neuronal migration. Adv. Exp. Med. Biol 2014, 800, 25-36.

10. Romaniello, R.; Arrigoni, F.; Bassi, M.T.; Borgatti, R. Mutations in $\alpha$ - and $\beta$-tubulin encoding genes: Implications in brain malformations. Brain Dev. 2015, 37, 273-280. [CrossRef]

11. Jaglin, X.H.; Chelly, J. Tubulin-related cortical dysgeneses: Microtubule dysfunction underlying neuronal migration defects. Trends Genet. 2009, 25, 555-566. [CrossRef] [PubMed]

12. Keays, D.A.; Tian, G.; Poirier, K.; Huang, G.J.; Siebold, C.; Cleak, J.; Piñon, M.C. Mutations in alpha-tubulin cause abnormal neuronal migration in mice and lissencephaly in humans. Cell 2007, 128, 45-57. [CrossRef] [PubMed]

13. Mutch, C.A.; Poduri, A.; Sahin, M.; Barry, B.; Walsh, C.A.; Barkovich, A.J. Disorders of microtubule function in neurons: Imaging correlates. Ajnr. Am. J. Neuroradiol. 2016, 37, 528-535. [CrossRef] [PubMed] 
14. Tischfield, M.A.; Engle, E.C. Distinct alpha- and beta-tubulin isotypes are required for the positioning, differentiation and survival of neurons: New support for the 'multi-tubulin' hypothesis. Biosci. Rep. 2010, 30, 319-330. [CrossRef] [PubMed]

15. Kumar, R.A.; Pilz, D.T.; Babatz, T.D.; Cushion, T.D.; Harvey, K.; Topf, M.; Rees, M.I. TUBA1A mutations cause wide spectrum lissencephaly (smooth brain) and suggest that multiple neuronal migration pathways converge on alpha tubulins. Hum. Mol. Genet. 2010, 19, 2817-2827. [CrossRef] [PubMed]

16. Singh, K.K.; Tsai, L.H. Micro TUB (B3) ules and brain development. Cell 2009, 140, 30-32. [CrossRef]

17. Tischfield, M.A.; Cederquist, G.Y.; Gupta, M.L., Jr.; Engle, E.C. Phenotypic spectrum of the tubulin-related disorders and functional implications of disease-causing mutations. Curr. Opin. Genet. Dev. 2011, 21, 286-294. [CrossRef]

18. Cushion, T.D.; Dobyns, W.B.; Mullins, J.G.; Stoodley, N.; Chung, S.K.; Fry, A.E.; Uyanik, G. Overlapping cortical malformations and mutations in TUBB2B and TUBA1A. Brain 2013, 136, 536-548. [CrossRef]

19. Poirier, K.; Saillour, Y.; Bahi-Buisson, N.; Jaglin, X.H.; Fallet-Bianco, C.; Nabbout, R.; Genevieve, D. Mutations in the neuronal $\beta$-tubulin subunit TUBB3 result in malformation of cortical development and neuronal migration defects. Hum. Mol. Genet. 2010, 19, 4462-4473. [CrossRef]

20. Morris-Rosendahl, D.J.; Najm, J.; Lachmeijer, A.M.A.; Sztriha, L.; Martins, M.; Kuechler, A.; Vasconcelos, C. Refining the phenotype of alpha-1a Tubulin (TUBA1A) mutation in patients with classical lissencephaly. Clin. Genet. 2008, 74, 425-433. [CrossRef]

21. Tian, G.; Jaglin, X.H.; Keays, D.A.; Francis, F.; Chelly, J.; Cowan, N.J. Disease-associated mutations in TUBA1A result in a spectrum of defects in the tubulin folding and heterodimer assembly pathway. Hum. Mol. Genet. 2010, 19, 3599-3613. [CrossRef] [PubMed]

22. Jansen, A.C.; Oostra, A.; Desprechins, B.; De Vlaeminck, Y.; Verhelst, H.; Regal, L.; Verloo, P.; Bockaert, N.; Keymolen, K.; Seneca, S.; et al. TUBA1A mutations: From isolated lissencephaly to familial polymicrogyria. Neurology 2011, 76, 988-992. [CrossRef] [PubMed]

23. Romaniello, R.; Tonelli, A.; Arrigoni, F.; Baschirotto, C.; Triulzi, F.; Bresolin, N.; Borgatti, R. A novel mutation in the $\beta$-tubulin gene TUBB2B associated with complex malformation of cortical development and deficits in axonal guidance. Dev. Med. Child. Neurol. 2012, 54, 765-769. [CrossRef] [PubMed]

24. Sohal, A.P.; Montgomery, T.; Mitra, D.; Ramesh, V. TUBA1A mutation-associated lissencephaly: Case report and review of the literature. Pediatr. Neurol. 2012, 46, 127-131. [CrossRef] [PubMed]

25. Okumura, A.; Hayashi, M.; Tsurui, H.; Yamakawa, Y.; Abe, S.; Kudo, T.; Yamamoto, T. Lissencephaly with marked ventricular dilation, agenesis of corpus callosum, and cerebellar hypoplasia caused by TUBA1A mutation. Brain Dev. 2013, 35, 274-279. [CrossRef]

26. Poirier, K.; Saillour, Y.; Fourniol, F.; Francis, F.; Souville, I.; Valence, S.; Beldjord, C. Expanding the spectrum of TUBA1A-related cortical dysgenesis to Polymicrogyria. Eur. J. Hum. Genet. 2013, 21, 381-385. [CrossRef]

27. Zanni, G.; Colafati, G.S.; Barresi, S.; Randisi, F.; Talamanca, L.F.; Genovese, E.; Bertini, E. Description of a novel TUBA1A mutation in Arg-390 associated with asymmetrical polymicrogyria and mid-hindbrain dysgenesis. Eur. J. Paediatr. Neurol. 2013, 17, 361-365. [CrossRef]

28. Amrom, D.; Tanyalcin, I.; Verhelst, H.; Deconinck, N.; Brouhard, G.J.; Décarie, J.C.; Michaud, J.L. Polymicrogyria with dysmorphic basal ganglia? Think tubulin! Clin. Genet. 2014, 85, 178-183. [CrossRef]

29. Blumkin, L.; Halevy, A.; Ben-Ami-Raichman, D.; Dahari, D.; Haviv, A. Expansion of the spectrum of TUBB4A-related disorders: A new phenotype associated with a novel mutation in the TUBB4A gene. Neurogenetics 2014, 15, 107-113.

30. Hikita, N.; Hattori, H.; Kato, M.; Sakuma, S.; Morotomi, Y.; Ishida, H.; Tokuhara, D. A case of TUBA1A mutation presenting with lissencephaly and Hirschsprung disease. Brain Dev. 2014, 36, 159-162. [CrossRef]

31. Shimojima, K.; Narita, A.; Maegaki, Y.; Saito, A.; Furukawa, T.; Yamamoto, T. Whole-exome sequencing identifies a de novo TUBA1A mutation in a patient with sporadic malformations of cortical development: A case report. BMC Res. Notes 2014, 7, 465. [CrossRef] [PubMed]

32. Myers, K.A.; Bello-Espinosa, L.E.; Kherani, A.; Wei, X.C.; Innes, A.M. TUBA1A Mutation associated with eye abnormalities in addition to brain malformation. Pediatr. Neurol. 2015, 53, 442-444. [CrossRef] [PubMed]

33. Yokoi, S.; Ishihara, N.; Miya, F.; Tsutsumi, M.; Yanagihara, I.; Fujita, N.; Yamasaki, M. TUBA1A mutation can cause a hydranencephaly-like severe form of cortical dysgenesis. Sci. Rep. 2015, 5, 15165. [CrossRef] [PubMed] 
34. Bahi-Buisson, N.; Cavallin, M. Tubulinopathies Overview. In GeneReviews®; Adam, M.P., Ardinger, H.H., Pagon, R.A., Wallace, S.E., Bean, L.J.H., Stephens, K., Amemiya, A., Eds.; University of Washington: Seattle, WA, USA, 2016.

35. Laquerriere, A.; Gonzales, M.; Saillour, Y.; Cavallin, M.; Joyē, N.; Quēlin, C.; Chelly, J. De novo TUBB2B mutation causes fetal akinesia deformation sequence with microlissencephaly: An unusual presentation of tubulinopathy. Eur. J. Med. Genet. 2016, 59, 249-256. [CrossRef]

36. Gardner, J.; Cushion, T.; Niotakis, G.; Olson, H.; Grant, P.; Scott, R.; Bonnières, M. Clinical and functional characterization of the recurrent TUBA1A p. (Arg2His) mutation. Brain Sci. 2018, 8, 145. [CrossRef]

37. Romaniello, R.; Arrigoni, F.; Fry, A.E.; Bassi, M.T.; Rees, M.I.; Borgatti, R.; Cushion, T.D. Tubulin genes and malformations of cortical development. Eur. J. Med. Genet. 2018, 61, 744-754. [CrossRef]

38. Sato, T.; Kato, M.; Moriyama, K.; Haraguchi, K.; Saitsu, H.; Matsumoto, N.; Moriuchi, H. A case of tubulinopathy presenting with porencephaly caused by a novel missense mutation in the TUBA1A gene. Brain Dev. 2018, 40, 819-823. [CrossRef]

39. Wang, H.; Li, S.; Li, S.; Jiang, N.; Guo, J.; Zhang, W.; Xie, J. De novo mutated TUBB2B associated pachygyria diagnosed by medical exome sequencing and long-range PCR. Fetal Pediatr. Pathol. 2018, 1-9. [CrossRef]

40. Oegema, R.; Cushion, T.D.; Phelps, I.G.; Chung, S.K.; Dempsey, J.C.; Collins, S.; Dobyns, W.B. Recognizable cerebellar dysplasia associated with mutations in multiple tubulin genes. Hum. Mol. Genet. 2015, 24, 5313-5325. [CrossRef]

41. Romaniello, R.; Arrigoni, F.; Panzeri, E.; Poretti, A.; Micalizzi, A.; Citterio, A.; Ferraris, A. Tubulin-related cerebellar dysplasia: Definition of a distinct pattern of cerebellar malformation. Eur. Radiol. 2017, 27, 5080-5092. [CrossRef]

42. Arrigoni, F.; Romaniello, R.; Peruzzo, D.; Poretti, A.; Bassi, M.T.; Pierpaoli, C.; Triulzi, F. The spectrum of brainstem malformations associated to mutations of the tubulin genes family: MRI and DTI analysis. Eur. Radiol. 2019, 29, 770-782. [CrossRef] [PubMed]

43. Leventer, R.J.; Guerrini, R.; Dobyns, W.B. Malformations of cortical development and epilepsy. Dialog. Clin. Neurosci. 2008, 10, 47-62.

44. Romaniello, R.; Arrigoni, F.; Cavallini, A.; Tenderini, E.; Baschirotto, C.; Triulzi, F.; Borgatti, R. Brain malformations and mutations in $\alpha$ - and $\beta$-tubulin genes: A review of the literature and description of two new cases. Dev. Med. Child. Neurol. 2014, 56, 354-360. [CrossRef] [PubMed]

45. Mencarelli, A.; Prontera, P.; Stangoni, G.; Mencaroni, E.; Principi, N.; Esposito, S. Epileptogenic brain malformations and mutations in tubulin genes: A case report and review of the literature. Int. J. Mol. Sci. 2017, 18, 2273. [CrossRef] [PubMed]

46. Poirier, K.; Keays, D.A.; Francis, F.; Saillour, Y.; Bahi, N.; Manouvrier, S.; Bienvenu, T. Large spectrum of lissencephaly and pachygyria phenotypes resulting from de novo missense mutations in tubulin alpha $1 \mathrm{~A}$ (TUBA1A). Hum. Mutat. 2007, 28, 1055-1064. [CrossRef]

47. Bahi-Buisson, N.; Poirier, K.; Boddaert, N.; Saillour, Y.; Castelnau, L.; Philip, N.; Bourgeois, M. Refinement of cortical dysgeneses spectrum associated with TUBA1A mutations. J. Med. Genet. 2008, 45, 647-653. [CrossRef]

48. Bahi-Buisson, N.; Poirier, K.; Fourniol, F.; Saillour, Y.; Valence, S.; Lebrun, N.; Lascelles, K. The wide spectrum of tubulinopathies: What are the key features for the diagnosis? Brain 2014, 137, 1676-1700. [CrossRef]

49. Rektor, I.; Kuba, R.; Bràzdil, M.; Chrastina, J. Do the basal ganglia inhibit seizure activity in temporal lobe epilepsy? Epilepsy Behav. 2012, 25, 56-59. [CrossRef]

50. Recio, M.V.; Gallagher, M.J.; McLean, M.J.; Abou-Khalil, B. Clinical features of epilepsy in patients with cerebellar structural abnormalities in a referral center. Epilepsy Res. 2007, 76, 1-5. [CrossRef]

51. Ivanova, E.L.; Gilet, J.G.; Sulimenko, V.; Duchon, A.; Rudolf, G.; Runge, K.; Tilly, P. TUBG1 missense variants underlying cortical malformations disrupt neuronal locomotion and microtubule dynamics but not neurogenesis. Nat. Commun. 2019, 10, 2129. [CrossRef]

52. Barkovich, J. Complication begets clarification in classification. Brain 2013, 136, 368-373. [CrossRef] [PubMed]

53. Breuss, M.; Keays, D.A. Microtubules and neurodevelopmental disease: The movers and the makers. Adv. Exp. Med. Biol. 2014, 800, 75-96. [PubMed]

54. Uribe, V. The beta-tubulin gene TUBB2B is involved in a large spectrum of neuronal migration disorders. Clin. Genet. 2010, 77, 34-35. [CrossRef] [PubMed] 
55. Breuss, M.; Morandell, J.; Nimpf, S.; Gstrein, T.; Lauwers, M.; Hochstoeger, T.; Suplata, M. The expression of tubb2b undergoes a developmental transition in murine cortical neurons. J. Comp. Neurol. 2015, 523, 2161-2186. [CrossRef] [PubMed]

56. Jaglin, X.H.; Poirier, K.; Saillour, Y.; Buhler, E.; Tian, G.; Bahi-Buisson, N.; Castelnau-Ptakhine, L. Mutations in the beta-tubulin gene TUBB2B result in asymmetrical polymicrogyria. Nat. Genet. 2009, 41, 746-752. [CrossRef] [PubMed]

57. Cederquist, G.Y.; Luchniak, A.; Tischfield, M.A.; Peeva, M.; Song, Y.; Menezes, M.P.; Gomes, L. An inherited TUBВ2B mutation alters a kinesinbinding site and causes polymicrogyria, CFEOM, and axon dysinnervation. Hum. Mol. Genet. 2012, 21, 5484-5499. [CrossRef] [PubMed]

58. Guerrini, R.; Mei, D.; Cordelli, D.M.; Pucatti, D.; Franzoni, E.; Parrini, E. Symmetric polymicrogyria and pachygyria associated with TUBB2B gene mutations. Eur. J. Hum. Genet. 2012, 20, 995-998. [CrossRef]

59. Tischfield, M.A.; Baris, H.N.; Wu, C.; Rudolph, G.; Van Maldergem, L.; He, W.; Mackey, D.A. Human TUBB3 mutations perturb microtubule dynamics, kinesin interactions, and axon guidance. Cell 2010, 140, $74-87$. [CrossRef]

60. Saillour, Y.; Broix, L.; Bruel-Jungerman, E.; Lebrun, N.; Muraca, G.; Rucci, J.; Chelly, J. Beta tubulin isoforms are not interchangeable for rescuing impaired radial migration due to Tubb3 knockdown. Hum. Mol. Genet. 2013, 23, 1516-1526. [CrossRef]

61. Xu, X.; Shangguan, Y.; Lu, S.; Wang, W.; Du, C.; Xiao, F.; Yang, Y. Tubulin $\beta$-III modulates seizure activity in epilepsy. J. Pathol. 2017, 242, 297-308. [CrossRef]

62. Guerrini, R. Epilepsy in children. Lancet 2006, 367, 499-524. [CrossRef]

63. Nunez, P.L.; Srinivasan, R.; Fields, R.D. EEG functional connectivity, axon delays and white matter disease. Clin. Neurophysiol. 2015, 126, 110-120. [CrossRef] [PubMed]

64. Chu, C.J.; Tanaka, N.; Diaz, J.; Edlow, B.L.; Wu, O.; Hämäläinen, M.; Kramer, M.A. EEG functional connectivity is partially predicted by underlying white matter connectivity. Neuroimage 2015, 108, 23-33. [CrossRef] [PubMed]

(C) 2019 by the authors. Licensee MDPI, Basel, Switzerland. This article is an open access article distributed under the terms and conditions of the Creative Commons Attribution (CC BY) license (http://creativecommons.org/licenses/by/4.0/). 